УДК 349.2

\title{
НОРМИ ТРУДОВОГО ПРАВА ЯК РЕЗУЛЬТАТ УКЛАДЕННЯ КОЛЕКТИВНИХ ДОГОВОРІВ
}

\author{
O. Cmacis \\ Львівський національний університет імені Івана Франка, \\ вул. Університетська, 1, Львів, Україна, 79000, \\ e-mail: stasivoksana2304@gmail.com
}

Доведено, що у результаті укладення колективних договорів (угод), їхні деякі умови можуть визначатися як норми трудового права. Це пояснюється тим, що такі умови відповідають певним ознакам: мають загальний характер, формальну визначеність, виконання умов забезпечується силою державного примусу, а також мають ознаки системності та регулятивності.

Наголошено й на тому, що діюче трудове законодавство України містить заборону обмежувати законні права працівників та їхніх законних представників з боку державних органів, політичних партій чи роботодавців при укладенні колективних договорів, угод.

Окрім того, обґрунтовано доцільність вживання єдиного терміна «колективні договори» замість двох термінів-синонімів «колективний договір» та «колективні угоди».

Ключові слова: колективний договір, угода, умови договору, договірний акт, норма права.

DOI: http://dx.doi.org/10.30970/vla.2020.70.189

Вже досить тривалий час як науковці, так і політики говорять про необхідність реформування трудового законодавства. У зв'язку з цим на сайті Верховної Ради неодноразово з'являлися різні за своєю суттю версії проектів Трудового кодексу, а останній проект отримав назву Закон про працю. Проте і досі продовжує діяти прийнятий ще в минулому столітті Кодекс законів про працю. Очевидно, що запропоновані проекти так і не були прийняті через свою недосконалість. Тому дослідження науковців, щодо їхнього змісту, коло суспільних відносин, які мають бути ними врегульовані та відносини, які мають врегульовуватися на рівні колективного регулювання, залишаються актуальними.

Серед науковців дослідженням колективних договорів та угод, їхніх умов та значення для регулювання трудових відносин займалися В. Венедіктов, Н. Болотіна, Р. Кондратьєв, 3. Козак, П. Пилипенко, О. Ярошенко інші.

Мета статті - дослідити, чи мають умови колективних договорів (угод) ознаки норм права.

Загальновідомим є той факт, що колективний договір, а також угоду укладають на основі чинного законодавства, прийнятих сторонами зобов'язань з метою регулювання виробничих, трудових і соціально-економічних відносин та узгодження інтересів працівників і роботодавців. Науковці досить тривалий час дискутують стосовно того, чи можна деякі умови таких договорів, угод визначити як норми права. Переважно проти такої ідеї виступають представники цивільного права, які стверджують, що умови будь-якого договору $\epsilon$ результатом домовленості між сторонами і не можуть набувати ознак норми права [7, с. 250’255].

Нагадаємо, що норми права мають відповідні ознаки, за якими їх можна ідентифікувати. Нормам притаманний загальний характер, тобто вони поширюються (C) Стасів О., 2020 
на всіх осіб, незалежно від їхньої обізнаності з цими нормами, крім того розраховані на багаторазове застосування. При цьому зауважимо, що припис правової норми може набувати зобов'язуючого, дозвільного чи заборонного характеру.

Нормам властива також формальна визначеність, тобто вони,мають міститися в офіційному джерелі права (нормативно-правовому акті, міжнародно-правовому договорі тощо). Така норма має бути конкретною та чіткою, визначаючи належну поведінку відповідного суб'єкта, закріплювати його суб'єктивні права або юридичні обов'язки.

Також норма або повинна встановлюватися державою шляхом прийняття закону чи то підзаконного нормативно-правового акта, або ж визначається нею, наприклад, через ратифікацію міжнародного договору. Проте зв’язок норми з державою проявляється і в тому, що виконання норми гарантується через застосування примусу з боку держави.

Крім того, праву загалом характерна системність, яка проявляється в єдності та погодженості всіх діючих норм права держави. При цьому норма права - це його своєрідна мікросистема, яка має структуру (гіпотеза, диспозиція, санкція). Всі норми пов'язані між собою та утворюють систему права.

I останне. Норма права повинна бути регулятором суспільних відносин, а також засобом вирішення конфліктів між суб'єктами [3, с. 276].

Спробуємо дослідити, чи відповідають умови колективних договорів та угод цим ознакам, а отже чи мають ознаки норм права.

Колективний договір укладають на підприємствах, в установах, організаціях незалежно від форм власності і господарювання, які використовують найману працю та мають право юридичної особи, а також може бути укладений у структурних підрозділах підприємства в межах компетенції цих підрозділів [4]. Під такими підрозділами маються на увазі цехи, відділи, сектори тощо. Натомість угоду укладають на національному, галузевому, територіальному рівнях на двосторонній або тристоронній основі: на національному рівні - генеральна угода; на галузевому рівні - галузеві (міжгалузеві) угоди; на територіальному рівні територіальні угоди [4].

Умови цих актів договірного характеру повинні відповідати низці вимог, які визначені законодавством, зокрема Законом «Про колективні договори та угоди». По-перше, умови колективних договорів і угод $є$ обов'язковими для підприємств, на які вони поширюються, та сторін, які їх уклали. По-друге, умови колективних договорів або угод, що погіршують порівняно з чинним законодавством становище працівників, є недійсними, i тому їх не можна долучати до їхнього змісту. Потрете, заборонено долучати до трудових договорів умови, що погіршують становище працівників порівняно з чинним законодавством, колективними договорами та угодами.

Необхідно наголосити й на тому, що чинне законодавство України також забороняє будь-яке втручання, яке може обмежити законні права працівників та їхніх представників або заборонити їхне здійснення, 3 боку органів як представницької, так і виконавчої влади чи господарського управління, політичних партій, роботодавців при укладенні та виконанні цих актів договірного характеру. Ці та інші правила прийняття колективних договорів та угод закріплені в трудовому законодавстві і вимагають обов'язкового дотримання. Водночас їхні окремі умови можуть покращувати та встановлювати нові гарантії для працівників порівняно з тими, що визначені трудовим законодавством. 
Отже, вищезазначені правила, є ознакою системності, яка притаманна нормам права, адже вони є елементом та в своїй сукупності утворюють цілісну систему національного трудового права.

Також зауважимо, що метою укладення цих договірних актів є регулювання виробничих, трудових і соціально-економічних відносин та узгодження інтересів працівників і роботодавців. Наприклад, Генеральною угодою на 2019-2020 роки Встановлено, що за роботу працівників у важких і шкідливих умовах праці встановлено надбавку 4, 8 і 12 відсотків тарифної ставки (окладу), а за роботу в особливо важких і особливо шкідливих умовах праці - 16, 20 і 24 відсотки тарифної ставки (окладу). Роботодавці, які підпадають під іiі дію зобов’язуються дотримуватися цього нормативного положення, а працівники своєю чергою мають право вимагати виконання. В колективному договорі ЛНУ імені Івана Франка на 2017-2020 роки, притримуючись такої умови Генеральної угоди, закріплено, що таким працівникам відповідно встановлюється надбавка до 12 відсотків за роботу у важких та шкідливих умовах праці та до 24 відсотків за роботу в особливо важких та шкідливих умовах праці. Очевидно, що положення колективного договору тільки дублює умову Генеральної угоди, а тому має не регулюючий, а інформативний характер. Проте у цьому локальному акті $є$ інші умови, що мають регулюючий характер. Представникам Профкому та Університету, делегованим до благодійного фонду, за наявності коштів сприяти в отриманні благодійної допомоги на кожен семестр працівниками Університету, для яких робота в Університеті є основним місцем праці, 3 метою компенсації витрат на навчання дітей в Університеті залежно від їхнього стажу роботи: більше ніж 5 років стажу - 20\%; більше ніж 10 років стажу - 30\%; більше ніж 15 років стажу - 50\% від розміру вартості навчання. У разі невиконання умов таких договірних актів працівники можуть звернутися до суду.

Отже, очевидно, що умови колективних договорів та угод є обов'язковими до виконання сторонами, які їх уклали та регулюють між ними соціальні відносини, а тому можна виокремити наступну регулятивну ознаку, притаманну нормам права.

Вимоги до змісту умов як колективного договору, так і угод є однаковими. Єдине, про що треба пам'ятати, це те, що зміст угоди, договору, нижчого рівня не повинен суперечити змісту угоди вищого рівня, а також погіршувати становище працівників, звужувати зміст їхніх прав. При цьому законодавством визначено, що положення колективного договору поширюються на всіх працівників підприємств незалежно від того, чи $є$ вони членами профспілки, і $є$ обов'язковими як для роботодавця, так і працівників. Положення ж генеральної, галузевої, територіальної угод діють безпосередньо і є обов'язковими для всіх суб'єктів, що перебувають у сфері дії сторін, які підписали угоду [4].

3 огляду на ці правила такі колективні договори та угоди у науковій літературі називають ще нормативними договорами про працю [6]. Попри це зауважимо, що у міжнародних актах до них застосовують єдиний термін - колективні договори. Рекомендацією МОП № 91 закріплено, що колективний договір - це усі письмові угоди щодо умов праці та найму, які укладають, з одного боку, між роботодавцем, групою роботодавців або однією чи кількома організаціями роботодавців та, 3 іншого боку, однією чи кількома представницькими організаціями працівників або, за відсутності таких організацій, представниками самих працівників, належно обраними й уповноваженими згідно зі законодавством країни [5].

За своєю суттю як колективні договори, так і колективні угоди є договорами, адже сторони між собою домовляються щодо регулювання виробничих, трудових i 
соціально-економічних відносин та узгодження інтересів працівників і роботодавців. Та й зі змісту чинного трудового законодавства не можна чітко визначити відмінність між термінами «договір» та «угода». Вважаємо, що вона полягає тільки у їхній сфері дії та сторонами, які наділені репрезентативністю укладення таких договорів і угод.

Якщо звернутися до «Великого тлумачного словника сучасної української мови», то під угодою необхідно розуміти: 1. Взаємну домовленість про що-небудь; 2. Договір, за яким встановлюються взаємні зобов'язання, щодо чого-небудь [1, c. 1495]. Натомість поняття договору визначається як взаємне зобов'язання, письмова або усна угода про права та обов'язки між державами, установами, підприємствами та окремими особами [1, с. 311]. Отож, очевидно, що поняття «угода» та «договір» вживають як синоніми.

У національному законодавстві теж видається недоцільним розділяти ці поняття, а для більш ефективного та однозначного сприйняття нормативно-правових актів, частиною яких є і згадувана вище Рекомендація МОП, варто вживати термін договір, що в подальшому і пропонуємо робити.

Варто також зазначити, що якщо 3 погляду цивільного права договір - це домовленість двох або більше сторін, що спрямована на встановлення, зміну та припинення цивільних прав та обов'язків (ч. 1 ст. 626 Цивільного Кодексу України), крім того, його зміст становлять, по-перше, умови, визначені на розсуд сторін і погоджені ними, та по-друге, умови, які є обов'язковими відповідно до актів цивільного законодавства, укладаються на його основі, то 3 погляду трудового права зміст договору набуває дещо інших специфічних рис.

Нагадуємо, що колективний договір укладають на підприємствах, що мають статус юридичної особи, а також на структурних підрозділах підприємства в межах їхньої компетенції. На нормативний характер цього локального акту вказує саме його сфера дії. Адже положення такого колективного договору поширюються на всіх працівників підприємства, де його укладено, незалежно від того, чи працівник, наприклад, входить до складу профспілки, що була стороною договору, чи влаштувався працювати на підприємство після його укладення. Такі положення $\epsilon$ обов'язковими як для роботодавця, так і його працівників, а тому цей договір ще називають локальним нормативним актом.

Натомість угоди (договори) згідно зі ст. 2 цього ж Закону укладають на національному, галузевому, територіальному рівнях на двосторонній або тристоронній основі: на національному рівні - генеральна угода; на галузевому рівні - галузеві (міжгалузеві) угоди; на територіальному рівні - територіальні угоди. Сдина норма у законодавстві, яка визначає сферу їхньої дії міститься у ч. 1 ст. 9 Закону України «Про колективні договори і угоди», де зазначено, що положення генеральної, галузевої (міжгалузевої), територіальної угод діють безпосередньо і є обов'язковими для всіх суб'єктів, що перебувають у сфері дії сторін, які підписали угоду.

Водночас, у Генеральній угоді, укладеній між всеукраїнськими об’єднаннями організацій роботодавців в особі Спільного представницького органу сторони роботодавців на національному рівні, всеукраїнськими об'єднаннями професійних спілок в особі Спільного представницького органу репрезентативних всеукраїнських об'єднань профспілок на національному рівні та Кабінетом Міністрів України про регулювання основних принципів і норм реалізації соціально-економічної політики і трудових відносин в Україні на 2019-2021 роки зазначено, що ії положення діють безпосередньо і є обов'язковими для всіх суб'єктів, що перебувають у сфері дії Сторін, у тому числі під час розроблення та укладання галузевих (міжгалузевих) i 
територіальних угод, колективних договорів. Це означає, що їі положення є обов'язковими для всіх сторін, які укладають галузеві та територіальні договори, у тому випадку, якщо їхні сторони були представлені під час підписання Генеральної угоди.

Отже, 3 вищевикладеного виходить, що такі договори (угоди) не можуть поширюватися на підприємства, установи, організації, які не були представлені зі сторони роботодавця чи профспілки (об'єднання профспілок чи іншого уповноваженого працівниками органу), а також тих, які були представлені під час підписання Генеральної угоди тільки однією стороною. При цьому зауважимо, що якщо роботодавець згідно зі Законом України «Про організації роботодавців, їх об'єднання, права і гарантії їх діяльності» входить до організації роботодавців чи їх об'єднань, то положення такого договору на них поширюються, якщо це зазначено в статуті цих об'єднань.

Зміст вищевикладеного свідчить про загальний характер умов колективних договорів (угод), адже вони поширюють свою дію не тільки на суб'єктів, які брали участь у їх прийнятті, крім того, їхні умови розраховані на багатократну реалізацію.

За невиконання умов колективних договорів (угод), а також їхнє невиконання, для сторін встановлено відповідальність, яка регламентуються ст. 18-20 Закону України «Про колективні договори і угоди» та Кодексом України про адміністративні правопорушення. При цьому контроль за дотриманням цих актів покладено на самі сторони або орган, який брав участь у їхньому укладенні. Наприклад, контроль за виконанням Генеральної угоди 2019-2021 років забезпечує Спільна робоча комісія, яка вела переговори щодо їі укладення. Також контроль за виконанням Галузевої угоди між Міністерством освіти і науки України та ЦК Профспілки працівників освіти і науки України на 2016-2020 роки здійснює теж спільна комісія Міністерства освіти і науки України та ЦК Профспілки працівників освіти і науки України. Натомість за невиконання умов колективного договору ЛНУ імені Івана Франка на 2017-2020 роки покладено на сторони, які його уклали, а саме ректора та голову Профкому.

На осіб, які представляють роботодавця чи профспілки або інші уповноважені трудовим колективом органи, із вини яких порушено чи не виконано зобов'язання щодо колективного договору (угоди), накладають штраф до ста неоподатковуваних мінімумів доходів громадян, і вони також несуть дисциплінарну відповідальність аж до звільнення 3 посади. При цьому на вимогу профспілок, іншого уповноваженого трудовим колективом органу роботодавець зобов'язаний вжити заходів, передбачених законодавством, до керівника, з вини якого порушено чи не виконуються зобов'язання щодо колективного договору (угоди).

Окрім того, відповідальність встановлена також для осіб, які представляють роботодавця чи профспілки або інші уповноважені трудовим колективом органи за ненадання інформації, необхідної для колективних переговорів і здійснення контролю за виконанням колективних договорів, угод у вигляді дисциплінарної відповідальності або підлягають штрафу дояти неоподатковуваних мінімумів доходів громадян [4].

При цьому порядок і строки накладення штрафів, регламентує Кодекс України про адміністративні правопорушення. Справи 3 цих питань розглядає суд за поданням однієї із сторін колективного договору або відповідних комісій. Отже, виконання умов колективних договорів забезпечує державний примус, що є ще однією ознакою норм права.

У науковій літературі цілком слушно стверджується, що колективні договори та угоди є джерелом права, оскільки це нормативно-правові договори. Норма- 
тивно-правовий договір може бути як двостороннім, так і багатостороннім, це угода, яка встановлює, змінює або скасовує норми права. Такі договори на відміну від індивідуально-правових договорів (наприклад, договору купівлі-продажу, шлюбного договору) містять загальні правила поведінки і не мають персоніфікованого характеру [2, с. 8-9].

Отже, колективні договори (угоди) можуть встановлювати норми права, $\epsilon$ результатом домовленості між сторонами, їня юридична сила та сфера дії залежать від правового статусу сторін, що їх уклали. Крім того, процедура укладення та набуття чинності визначена в законодавстві, а у випадку порушення умов колективних договорів може застосовуватися державний примус. 3 огляду на це вважаємо, що у результаті укладення колективних договорів, деякі їхні умови набувають ознак норм права. Ці договірні акти є джерелом права у нашій державі, а їхні умови мають нормативний характер.

\section{Список використаних джерел}

1. Великий тлумачний словник сучасної української мови: 250000 / уклад. та голов. ред. В. Т. Бусел. Київ; Ірпінь: Перун, 2005. VIII, 1728 с.

2. Заболотна Н. Я. Нормативно-правовий договір: деякі проблеми загальної теорії // Наше право. 2014. № 4. С. 5-10.

3. Крестовська Н. М., Матвеева Л. Г. Теорія держави і права: Елементарний курс. Видання друге. Харків: ТОВ «Одіссей», 2008. 432 с.

4. Про колективні договори і угоди: Закон України в ред. від 27.12.2019 р. Сайт Верховної Ради України. URL: https://zakon.rada.gov.ua/laws/show/3356-12

5. Рекомендація МОП щодо колективних договорів від 29.06.1951 р. Сайт Верховної Ради України. URL: N 91 https://zakon.rada.gov.ua/laws/show/993_231

6. Сімутіна Я. В. До питання визначення сфери дії колективних договорів та угод // Часопис Київського університету права. 2010. №2. С. 186-190.

7. Цивільне право України: навчальний посібник / кол. авторів; за ред. Г. Б. Яновицької, В. О. Кучера. Львів: Львівський державний університет внутрішніх справ, 2011. 468 с.

\section{References}

1. Velykyi tlumachnyi slovnyk suchasnoi ukrainskoi movy: 250 000. (2005). / uklad. ta holov. red. V. T. Busel. Kyiv; Irpin: Perun, VIII.

2. Zabolotna, N. Ya. (2014). Normatyvno-pravovyi dohovir: deiaki problemy zahalnoi teorii. Nashe pravo, № 4, 5-10.

3. Krestovska, N. M., Matveeva, L. H. (2008). Teoriia derzhavy i prava: Elementarnyi kurs. Vydannia druhe. Xarkiv: TOV «Odissei».

4. Pro kolektyvni dohovory i uhody: Zakon Ukrainy v red. vid 27.12.2019 r. Sait Verkhovnoi Rady Ukrainy. Retrieved from https://zakon.rada.gov.ua/laws/show/3356-12

5. Rekomendatsiia MOP shchodo kolektyvnykh dohovoriv vid 29.06.1951 r. Sait Verkhovnoi Rady Ukrainy. Retrieved from N 91 https://zakon.rada.gov.ua/laws/show/993_231

6. Simutina, Ya. V. (2010). Do pytannia vyznachennia sfery dii kolektyvnykh dohovoriv ta uhod. Chasopys Kyivskoho universytetu prava, № 2, 186-190.

7. Tsyvilne pravo Ukrainy: navchalnyi posibny. (2011). / kol. avtoriv; za red. H. B. Yanovytskoi, V. O. Kuchera. Lviv: Lvivskyi derzhavnyi universytet vnutrishnikh sprav. 


\title{
LABOR LAW NORMS AS A RESULT OF COLLECTIVE AGREEMENTS
}

\author{
O. Stasiv \\ Ivan Franko National University of Lviv, \\ 1, Universytetska Str., Lviv, Ukraine, 79000, \\ e-mail: stasivoksana2304@gmail.com
}

The article proves that as a result of concluding collective contracts (agreements), some of their terms can be defined as labor law norms. This is due to the fact that such conditions correspond to the following characteristics: they have a general character, formal certainty, the fulfillment of conditions is ensured by the force of state coercion, and they also have features of system and regulation.

However, the terms of collective agreements shall meet a number of requirements defined by the law.

First, the terms of collective contracts and agreements are binding on the enterpreneuerships that they apply to and the parties that have entered into them.

Second, the terms of collective contracts or agreements that worsen the situation of employees in comparison with the current legislation are invalid, and therefore they cannot be included in their contents.

Third, it is prohibited to include in employment contracts conditions that worsen the situation of employees in comparison with the current legislation, collective contracts and agreements.

It should be noted that the current legislation of Ukraine also prohibits any interference that may restrict the legal rights of employees and their representatives or prohibit their exercise by the representative and executive authorities as well as commercial management, political parties, and employers in the conclusion and execution of these acts of a contractual nature. These and other rules for the adoption of collective contracts and agreements are enshrined in labor legislation and require mandatory compliance. However, their individual conditions may improve and establish new guarantees for employees in comparison with those defined by the labor legislation.

Besides that, liability is also set for persons, who represent employers, trade unions or other accredited by workforce bodies. The liability goes to action in case information, needed for collective negotiations and implementing rightful control over collective negotiations, is not provided. It is done through agreements of disciplinary liability or fines amounting to 5 tax-free minimum incomes of citizens. The terms and order of applying fines are foreseen in the Code of Ukraine on Administrative Offences. Cases of this kind are considered if one of the parties or relevant commision sued collective agreement. Thus, implementing the conditions of collective agreements is secured by state coercion which is another feature of the rule of law.

In addition, the author justifies the expediency of using the single term "collective agreements" instead of the terms "collective agreement and collective contracts", since the latter are essentially all agreements.

Keywords: collective agreement, contract, terms of the agreement, contract act, rule of law.

Стаття: надійшла до редакції 15.04.2020

прийнята до друку 12.06.2020 